\title{
Systematic review of 241 laparoscopic isolated liver segment VII resections
}

\author{
Kutay Sağlam, (๑) Örgün Güneş, @ Yusuf Murat Bağ, @ Mehmet Can Aydın, \\ (D) Fatih Sümer, () Cüneyt Kayaalp \\ Department of General Surgery, İnönü University, Malatya, Turkey
}

\begin{abstract}
Laparoscopic liver resections are performed with increasing frequency; however, they are less preferred for the deep parts of liver because of difficulty in reaching a posterior superior segment and working in a narrow area. The aim of this study is to analyze the outcomes of laparoscopic segment 7 resections with two new patients and previously published 239 patients.

PubMed, Scopus, and Google Scholar databases were scanned for the topic with several keywords. Eligible studies were selected for the analysis and reference cross-check was added to the search. Surgical technique details (application of Pringle maneuver, using Cavitron ultrasonic surgical aspirator (CUSA), patient position, Glissonean approach, and intercostal trocar (ICT) placement) were examined for the outcomes (operating time, blood loss, conversion to open surgery, and post-operative complications).

Total data of 239 cases were collected from 27 studies and we added two more cases from our clinic. Lateral decubitus patient position was with less post-operative complications when compared to the supine position $(8.4 \%$ vs. $50.0 \%, p=0.01)$. ICT placement seemed to have less conversion rate $(1.3 \%$ vs. $7.3 \%, p=0.07)$ and less post-operative complications ( $4.5 \%$ vs. $19.1 \%, p=0.05)$. Glissonean approach increased the operating time but had no effect on blood loss. Using CUSA for parenchymal transection lowered the rates of post-operative complications ( $4.4 \%$ vs. $19.5 \%, \mathrm{p}<0.05$ ) but it was not useful for blood loss or operating time. Application of Pringle maneuver had no effect on these outcomes.

Laparoscopic isolated segment 7 liver resection is a feasible surgical procedure for selected patients in centers with experienced surgeons on advanced laparoscopy. Lateral decubitus patient position, ICT placement, and using CUSA for parenchymal transection seem beneficial to decrease conversion to open surgery and complication rates. Pringle maneuver or Glissonean approach were not found as useful for the outcomes.

Keywords: Hepatectomy; laparoscopy; minimal invasive surgery; segment seven; segmentectomy.
\end{abstract}

\section{Introduction}

Since the first laparoscopic liver resection was reported in the 90s, laparoscopic approaches to liver have become more common. ${ }^{[1]}$ Compared to open resections, laparoscopic liver resections are more comfortable in the post-operative period, and there are no differences in oncologic outcomes. ${ }^{[2]}$ Laparoscopic resections are more frequently performed in easily visualizable segments of liver 
(segments 2, 3, 4B, 5, 6), while limitations remain for the segments that are difficult to reach (segments 1, 4A, 7, 8). ${ }^{[3]}$ The liver is surrounded by diaphragm and ribs, which results in a narrow operation area; difficulty in accessing the posterior segments, revealing the lesion, resection with appropriate surgical margin, and control the bleeding ${ }^{[2]}$ (Fig. 1a, b). However, with the development of laparoscopic techniques, technological devices, and experience, approach to posterior liver segments has become more applicable.

The aim of this article is to present two patients who underwent isolated laparoscopic segment 7 resection and investigate the effects of surgical technique details; including application of Pringle maneuver, Cavitron ultrasonic surgical aspirator (CUSA) usage, patient's position, Glissonean approach, and intercostal trocar (ICT) placement, on surgical and clinical outcomes; operating time, blood loss, conversion to open surgery, and post-operative complications with a systematic literature review.

Case 1 - A 26-year-old male patient had a history of the right hemicolectomy at the age of 15 years old for colon cancer, followed by chemotherapy. There was no additional feature in his and family's medical history. Physical examination revealed a median incision scar from the previous operation. Contrast-enhanced abdominal tomography and dynamic magnetic resonance imaging showed a $60 \mathrm{~mm} \times 50 \mathrm{~mm}$ sized solid mass with lobulated contours at segment $6-7$, which appeared in recent year (Fig. 2 a). Laboratory examination revealed; CEA: 0.89, CA19-9: 32.5, and hydatid cyst antigens were negative. Percutaneous biopsy was performed but pathological examination was not diagnostic, and malignancy could not be ruled out. The patient was scheduled for laparoscopic liver resection.

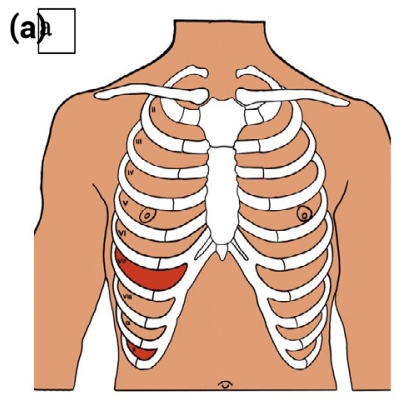

(b)

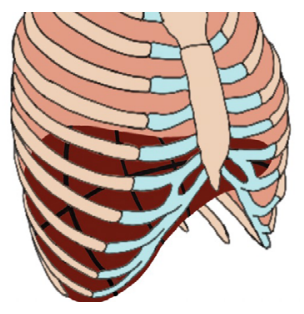

Figure 1. Location of segment 7 in liver.
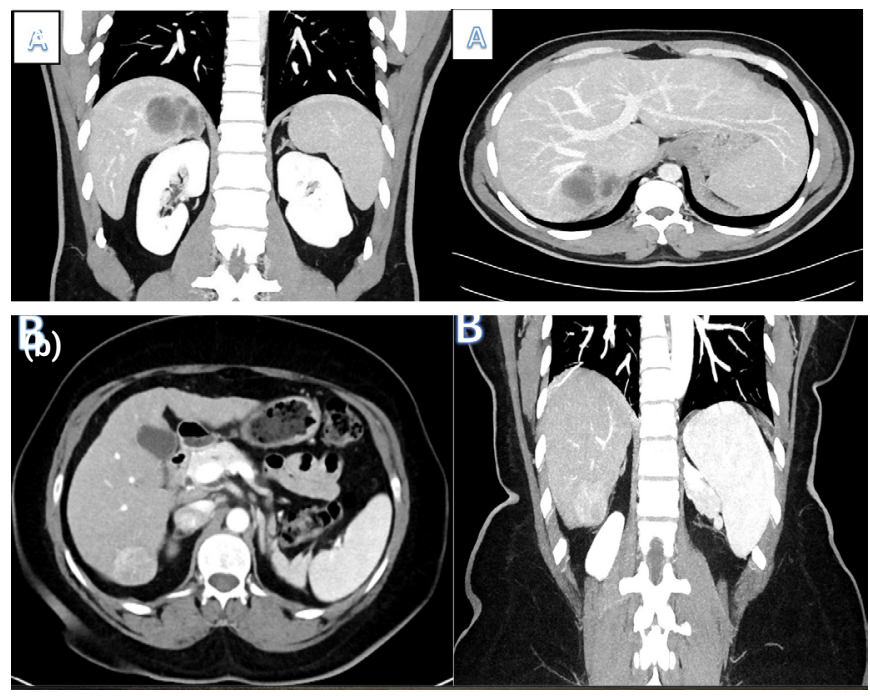

Figure 2. (a) Enhanced abdominal tomography showed 60 $\mathrm{mm} \times 50 \mathrm{~mm}$ mass in segment 7 (patient 1). (b) Enhanced abdominal tomography showed $35 \mathrm{~mm} \times 28 \mathrm{~mm}$ mass in segment 7 (patient 2).

The patient was placed in the left semi-lateral position, with the right side up at an angle of $45^{\circ}$, legs open, and the monitor at the head. After providing pneumoperitoneum (13 mmHg) with a Veress needle from the upper left quadrant (Palmer point). A $10-12 \mathrm{~mm}$ trocar was applied with open technique $2 \mathrm{~cm}$ above the umbilicus from the point of previous incision scar. Other three 10-12 mm trocars were placed below the rib, through the subcostal line. Moreover, two $5 \mathrm{~mm}$ non-ballooned trocars were inserted through the $9^{\text {th }}$ and $10^{\text {th }}$ intercostal spaces. Cholecystectomy was performed after exploration of the abdominal cavity. The Rummel tourniquet was placed to hang hepatoduodenal ligament for the Pringle maneuver. Falciform ligament was divided and, right triangular and coronary ligaments were released from the liver. The patient was turned to the left lateral decubitus position. By tilting the liver to the left with the help of gravity, we reached the mass. Intraoperative ultrasonography (USG) was not performed. First, the short hepatic veins were separated from the liver using Hem-o-lock clips. The mass was transected from the liver parenchyma by preserving the right hepatic vein by intermittent Pringle maneuver (15 min clamped, 5 min non-clamped). Laparoscopic CUSA was used for parenchymal dissection, Ligasure (Covidien, Mansfield, USA) for division of parenchyma, and Aquamantys System (Medtronic, Minneapolis, MN, USA) for hemostasis. The hepatocaval ligament was separated by laparoscopic linear stapler blue cartridge (Endo Gia, 60 mm, Covidi- 
en, Norwalk, CT, USA, or $60 \mathrm{~mm}$ Echelon) and the mass was resected. Glissonian approach was not used. Specimen was removed using previous upper midline incision through endobag. Fibrin sealant was applied to the cut surface following hemostasis (Tisseel, Baxter Deerfield, US). The amount of intraoperative hemorrhage was 300 cc. Pneumothorax was not observed. The ICT entrance sites were not sutured. The operation time was $480 \mathrm{~min}$. Hemodynamic parameters were normal in the post-operative period. Blood transfusion was not required. On the $1^{\text {st }}$ post-operative day, patient's bowel movements started, and liquid food was allowed. Bile leakage was not observed. The drain was removed on the $4^{\text {th }}$ post-operative day. The patient was discharged on the $5^{\text {th }}$ post-operative day. The pathological examination reported a $6.5 \mathrm{~cm} \times$ $5 \mathrm{~cm} \times 4.5 \mathrm{~cm}$ mass consistent with Fasciola hepatica. Post-operative anti-parasitic treatment was not given. Sixth month follow-up showed no complications.

Case 2 - A 53-year-old female patient underwent laparoscopic resection in another center for hepatocellular cancer (HCC) due to hepatitis C virus (HCV)-induced liver cirrhosis. After the failure of this operation, the patient was referred to our center. Medical history of the patient revealed HCV positivity diagnosed 2 years ago and HCVRNA returned to negative with anti-viral treatment. On physical examination, there was one trocar entry site under the umbilicus and three trocar entry sites throughout the right subcostal line. Contrast-enhanced abdominal tomography showed $35 \mathrm{~mm} \times 28 \mathrm{~mm}$ sized solid mass in segment 7 of liver (Fig. 2 b). Laboratory examination showed HCV antibody: (+), HCV-RNA: (-), AFP: $2563 \mathrm{ng} / \mathrm{ml}$, CEA $0.84 \mathrm{ng} / \mathrm{ml}$, and CA19.9: $39.7 \mathrm{U} / \mathrm{ml}$. The patient with Child class A cirrhosis was scheduled for surgery.

The patient's position was the same as the first case presented. After pneumoperitoneum $(13 \mathrm{mmHg})$ was obtained from the old umbilical trocar side, $12 \mathrm{~mm}$ port was applied for camera in that hole and, one $10-12 \mathrm{~mm}$ trocar was inserted $2 \mathrm{~cm}$ below the xyphoid, three of 10-12 $\mathrm{mm}$ trocars were placed throughout the subcostal line. A non-ballooned $5 \mathrm{~mm}$ trocar was inserted through the 10th intercostal space. Additional two $10-12 \mathrm{~mm}$ trocars were inserted between ICT and anterior iliac crest. Abdominal cavity was explored, falciform ligament was divided and right triangular and coronary ligaments were released. The Rummel tourniquet was suspended for the Pringle maneuver. The patient was turned to the left lat- eral decubitus position, and the liver was tilted to left by gravity. The tumor was visualized with the help of this maneuver. Intraoperative USG was not performed before the resection. CUSA was used for parenchymal dissection, Ligasure (Covidien, Mansfield, USA) was used for sealing the minor vessels, and Aquamantys (Medtronic, Minneapolis, MN, USA) was used for hemostasis as same as the first patient. Glissonian approach was not used. The specimen was removed from the suprapubic incision through endobag. Fibrin sealant (Tisseel, Baxter Deerfield, USA) was applied to the cut surface. Intraoperative hemorrhage was $3000 \mathrm{cc}$. One package of erythrocyte suspension was transfused intraoperatively. The $5 \mathrm{~mm}$ ICT site was not sutured. The operation time was approximately $10 \mathrm{~h}$. Hemodynamic parameters were normal in the early post-operative period. Patient's oral nutrition was started on the $2^{\text {nd }}$ post-operative day. On the post-operative day 4, one package of erythrocyte suspension was transfused. Pneumothorax or bile leakage was not observed. The drain was removed on the $4^{\text {th }}$ post-operative day. The patient was discharged on the $5^{\text {th }}$ post-operative day. Pathological examination showed HCC.

\section{Materials and Methods}

The PubMed, Scopus, and Google Scholar databases were scanned in July 2019 with the keywords "laparosco* (hepatectomy OR liver resection) (segment 7 OR segment VII OR posterosuperior OR posterolateral)" and 179 potential articles were selected for search. After exclusions and reference cross-check, we collected 27 eligible studies including 239 patients. We added our two patients to the systematic review (Fig. 3). Country, year, number of patients, age, gender, tumor size, patient position, intraoperative ultrasound usage, ICT usage, number and location of ICT, methods used for bleeding control (Glissonean approach, Pringle maneuver), usage of CUSA in parenchymal dissection, fibrin glue application on the cut surface, operation time, blood loss, blood transfusion, conversion to open surgery, complications, length of hospital stay, and pathological results were recorded (Tables 1-3).

Written informed consents were obtained from our patients. No Institutional Review Board approval was required for this report. 


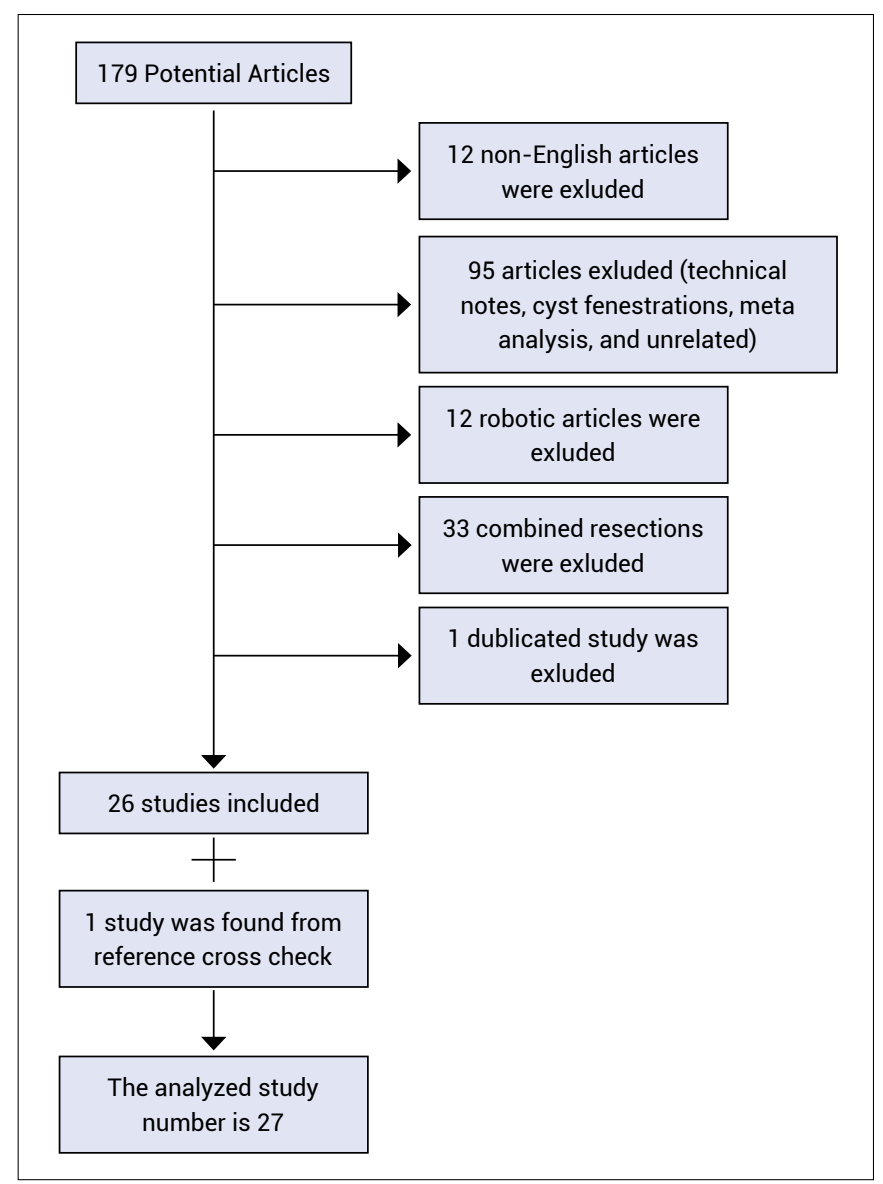

Figure 3. Flowchart of the literature review.

\section{Statistical Analysis}

For the studies which had reported median and range, the estimated mean and standard deviations were calculated using the method described by Hozo et al. ${ }^{[28]}$ Basic calculations were used for total numbers of dichotomous outcomes and weighted means for continuous outcomes. The Chi-square test or the Fisher's exact test (if expected values were $<5$ ) and the Student's t-test were used for statistical analysis of dichotomous and continuous variables, respectively (SPSS 13.0). $\mathrm{P}<0.05$ was considered statistically significant.

\section{Results}

A total of 241 patients were included in this systematic review and the mean age was $60.3 \pm 11.9$ years old $(61.5 \%$ male). The mean diameter of liver mass was $2.8 \pm 1.4 \mathrm{~cm}$. The left lateral decubitus position was preferred at a rate of $75.6 \%$. ICT was used in $39 \%$ of patients and, 7 th and 10th (73.3\%) intercostal port spaces were the most preferred ones. Intraoperative ultrasound was used in 81.3\% of the operations. In parenchymal transection, CUSA was preferred in $33.6 \%$ of the patients. The use of Pringle ma- neuver rate was $13.4 \%$. The rate of Glissonean approach was $13.4 \%$. The mean operation time was $302 \pm 629 \mathrm{~min}$, and the mean blood loss was $249 \pm 460 \mathrm{ml}$. The mean complication rate was $12 \%$, whereas bile leakage and pneumothorax were not reported in any. Mean hospitalization time was $7.9 \pm 3.3$ days. Major morbidity or mortality was not reported in any of 241 cases. In the pathology reports, metastatic masses (44.2\%) were the second most common lesion after HCC (47.7\%) (Table 4). The complication rates in of operations with patients in lateral decubitus position were significantly lower than with patients in supine position $(8.4 \%$ vs. $50 \%, p=0.01)$. In ICT placed group, conversion to open surgery (1.3\% vs. $7.3 \%, \mathrm{p}=0.07)$ and complication ( $4.5 \%$ vs. $19.1, \mathrm{p}=0.05)$ rates were lower than in non-ICT placed group. Although ICT use was not statistically significant on these parameters, it was suggestive. Glissonean approach increased the operating time (335 \pm 20 min vs. $226 \pm 89 \mathrm{~min}, \mathrm{p}=0.02)$ but had no significant effect on blood loss. Using CUSA for parenchymal transection lowered the rates of post-operative complications ( $4.4 \%$ vs. $19.5 \%, \mathrm{p}<0.05)$ but it had no significant effects on blood loss or the operating time. Application of Pringle maneuver had no effects on evaluated outcomes (Table 5).

\section{Discussion}

In this study, we presented two patients and systematically reviewed with the data of 239 patients previously reported, who underwent isolated laparoscopic segment 7 liver resection.

This study showed that complication rates were lower in patients operated in lateral decubitus position. However, lateral decubitus position had no significant effects on the operating time, blood loss, or conversion to open surgery. Laparoscopic surgical procedures for posterosuperior segments of the liver are less preferred than other segments, especially because of the difficulty in bleeding control and working in a narrow space. The position of the patient is very important for reaching the deepest part of the liver, segment 7. Although the left lateral decubitus position is generally preferred for visualization, there were also studies using supine and semi-prone positions in the literature. ${ }^{[24,25]}$ Ikeda et al. ${ }^{[8]}$ reported that patients operated in semi-prone position had less intraoperative blood loss and length of hospital stay than patients operated in supine position.

The use of CUSA in parenchymal transection did not af- 
Table 1. Publications and pre-operative patients' details

\begin{tabular}{|c|c|c|c|c|c|c|c|}
\hline Authors & Year & Country & No & Age & Gender & $\begin{array}{c}\text { Tumor } \\
\text { diameter }\end{array}$ & Patient position \\
\hline Hilal et al. ${ }^{[4]}$ & 2009 & UK & 1 & 60 & $M$ & 30 & NA \\
\hline Cho et al. ${ }^{[5]}$ & 2009 & Korea & 2 & NA & NA & NA & $\begin{array}{l}\text { Left semi-lateral } \\
\text { decubitus }\end{array}$ \\
\hline Cheng et al. ${ }^{[6]}$ & 2010 & China & 1 & 60 & $M$ & 26 & NA \\
\hline Kazaryan et al. ${ }^{[1]}$ & 2011 & Norway & 13 & NA & NA & NA & Left lateral decubitus \\
\hline Ishizawa et al. ${ }^{[7]}$ & 2012 & Japan & 6 & NA & NA & NA & Left lateral decubitus \\
\hline Ikeda et al. ${ }^{[8]}$ & 2014 & Japan & 17 & NA & NA & NA & Semi-prone \\
\hline Long et al. ${ }^{[9]}$ & 2014 & Vietnam & 7 & NA & NA & NA & Left lateral recumbent \\
\hline Coles et al. ${ }^{[10]}$ & 2014 & UK & 7 & $65( \pm 7.5)$ & $5 \mathrm{M} / 2 \mathrm{~F}$ & $13( \pm 6.9)$ & $\begin{array}{l}\text { Left semi-lateral } \\
\text { decubitus }\end{array}$ \\
\hline Lee et al..$^{[1]]}$ & 2014 & Korea & 3 & NA & NA & NA & $\begin{array}{l}\text { Left semi lateral } \\
\text { decubitus }\end{array}$ \\
\hline Okuda et al. ${ }^{[12]}$ & 2015 & Japan & 6 & $58.75( \pm 5.75)$ & $1 \mathrm{M} / 5 \mathrm{~F}$ & $15.5( \pm 4.5)$ & $\begin{array}{l}\text { Left semi-lateral } \\
\text { decubitus }\end{array}$ \\
\hline D'Hondt et al. ${ }^{[13]}$ & 2015 & Belgium & 14 & NA & NA & NA & Semi-prone \\
\hline \multirow[t]{2}{*}{ Ogiso et al. ${ }^{[2] *}$} & 2015 & USA & 15 & NA & NA & NA & $\begin{array}{l}\text { Left semi-lateral } \\
\text { decubitus }\end{array}$ \\
\hline & 2015 & USA & 11 & NA & NA & NA & $\begin{array}{l}\text { Left semi-lateral } \\
\text { decubitus }\end{array}$ \\
\hline Lim et al. ${ }^{[14]}$ & 2016 & Japan & 7 & NA & NA & NA & Left lateral decubitus \\
\hline Okuda et al. ${ }^{[15]}$ & 2017 & Japan & 3 & $53.5( \pm 12.5)$ & $3 \mathrm{M}$ & $35( \pm 2.5)$ & $\begin{array}{l}\text { Left semi-lateral } \\
\text { decubitus }\end{array}$ \\
\hline Zhang et al. ${ }^{[3]}$ & 2017 & China & 19 & NA & NA & NA & $\begin{array}{l}\text { Left semi-lateral } \\
\text { decubitus }\end{array}$ \\
\hline \multirow[t]{2}{*}{ Inoue et al. ${ }^{[16] \#}$} & 2017 & Japan & 15 & $64.75( \pm 12.75)$ & $8 \mathrm{M} / 7 \mathrm{~F}$ & NA & Left lateral decubitus \\
\hline & 2017 & Japan & 14 & $63.75( \pm 9.75)$ & $6 \mathrm{M} / 8 \mathrm{~F}$ & NA & Left lateral decubitus \\
\hline \multirow[t]{2}{*}{ Hirokawa et al. ${ }^{[17] \&}$} & 2017 & Japan & 14 & NA & NA & NA & $\begin{array}{c}\text { Left lateral decubitus } \\
\text { OR LSLD }\end{array}$ \\
\hline & 2017 & Japan & 9 & NA & NA & NA & $\begin{array}{l}\text { Left lateral decubitus } \\
\text { OR LSLD }\end{array}$ \\
\hline Chen et al. ${ }^{[18]}$ & 2017 & China & 4 & NA & $M$ & NA & Left Jack-knife \\
\hline D'Hondt et al. ${ }^{[19]}$ & 2017 & Belgium & 7 & NA & NA & NA & Semi-prone \\
\hline Giuliani et al. ${ }^{[20]}$ & 2017 & Italy & 1 & 60 & $M$ & 30 & Right lateral decubitus \\
\hline Ichida et al. ${ }^{[21]}$ & 2017 & Japan & 4 & NA & NA & NA & Left lateral decubitus \\
\hline Murata et al. ${ }^{[22]}$ & 2018 & Japan & 1 & 28 & $M$ & 18 & NA \\
\hline Lainas et al. ${ }^{[23]}$ & 2018 & France & 1 & 70 & $M$ & 37 & Left lateral decubitus \\
\hline Li et al. ${ }^{[24]}$ & 2018 & China & 12 & NA & NA & NA & Supine \\
\hline Mashchenko et al. ${ }^{[25]}$ & 2018 & Grenada & 7 & $50.75( \pm 9.75)$ & $5 \mathrm{M} / 2 \mathrm{~F}$ & $44.5( \pm 1.25)$ & Supine \\
\hline Kim et al. ${ }^{[26]}$ & 2019 & Korea & 1 & 76 & M & 52 & Supine \\
\hline Lee et al. ${ }^{[27]}$ & 2019 & Korea & 17 & $60.35( \pm 11.36)$ & $12 \mathrm{M} / 5 \mathrm{~F}$ & $2.6( \pm 1.0)$ & Left lateral decubitus \\
\hline Our case 1 & 2019 & Turkey & 1 & 26 & M & 65 & Left lateral decubitus \\
\hline Our case 2 & 2019 & Turkey & 1 & 53 & $\mathrm{~F}$ & 35 & Left lateral decubitus \\
\hline
\end{tabular}

*This article compared combined lateral and abdominal approach with only abdominal approach. \# and \&: These articles compared ICT and without ICT usage. No: Number of patients; NA: Not available data. 


\section{Table 2. Operative procedures details.}

Authors ICT ICT Pringle Glissonean Intraop. CUSA Fibrin Operation Blood Blood Conversion No. place maneuver approach USG glue time loss transfusion

$(\mathrm{ml} / \mathrm{g}) \quad(\mathrm{min})$

\begin{tabular}{|c|c|c|c|c|c|c|c|c|c|c|c|}
\hline Hilal et al. ${ }^{[4]}$ & NA & NA & NA & NA & 1 & 0 & NA & NA & NA & NA & 0 \\
\hline Cho et al. ${ }^{[5]}$ & 0 & 0 & 0 & 0 & 0 & 1 & 1 & NA & NA & NA & 1 \\
\hline $\begin{array}{l}\text { Cheng } \\
\text { et al. } .^{[6]}\end{array}$ & 0 & NA & NA & NA & NA & NA & NA & 510 & 800 & 0 & 0 \\
\hline $\begin{array}{l}\text { Kazaryan } \\
\text { et al. } .^{[1]}\end{array}$ & 0 & 0 & 0 & 0 & 1 & 0 & 0 & NA & NA & NA & NA \\
\hline $\begin{array}{l}\text { Ishizawa } \\
\text { et al. } .^{[7]}\end{array}$ & 2 & NA & 1 & 0 & 1 & 0 & 1 & $\begin{array}{c}180- \\
240\end{array}$ & $\begin{array}{l}100- \\
1100\end{array}$ & 0 & 0 \\
\hline Ikeda et al. ${ }^{[8]}$ & 1 & $7^{\text {th }}$ & 0 & 1 & 0 & 0 & 0 & NA & NA & NA & 0 \\
\hline Long et al. ${ }^{[9]}$ & 0 & 0 & 0 & 1 & NA & 0 & NA & NA & NA & NA & NA \\
\hline $\begin{array}{l}\text { Coles } \\
\text { et al. } .^{[10]}\end{array}$ & 0 & 0 & 1 & 0 & 1 & 1 & 1 & $\begin{array}{c}252 \\
( \pm 69)\end{array}$ & $\begin{array}{c}400 \\
( \pm 493)\end{array}$ & NA & 0 \\
\hline Lee et al.. ${ }^{[11]}$ & 27 & $\begin{array}{c}7^{\text {th }} \text { and } \\
9^{\text {th }}\end{array}$ & 1 & 0 & 1 & 1 & 1 & NA & NA & 0 & 0 \\
\hline $\begin{array}{l}\text { Okuda } \\
\text { et al. } .^{[12]}\end{array}$ & 1 & $9^{\text {th }}$ & 1 & 0 & 0 & 1 & 0 & $\begin{array}{c}250 \\
( \pm 45)\end{array}$ & $\begin{array}{c}75.5 \\
( \pm 32.5)\end{array}$ & 0 & 0 \\
\hline $\begin{array}{l}\text { D'Hondt } \\
\text { et al. }{ }^{[13]}\end{array}$ & 0 & 0 & 0 & 0 & 1 & 0 & 1 & NA & NA & NA & 0 \\
\hline Ogiso et al. ${ }^{[2]}$ & * 2 & NA & 1 & 0 & 1 & 0 & 0 & NA & NA & NA & 0 \\
\hline & 0 & 0 & NA & 0 & 1 & 0 & 0 & NA & NA & NA & 0 \\
\hline Lim et al. ${ }^{[14]}$ & NA & NA & NA & 0 & NA & NA & NA & NA & NA & NA & 0 \\
\hline $\begin{array}{l}\text { Okuda } \\
\text { et al. } .^{[15]}\end{array}$ & 16 & $\begin{array}{c}6^{\text {th }} \text { and } \\
8^{\text {th }}\end{array}$ & 1 & 1 & 0 & 1 & 0 & $\begin{array}{c}336 \\
( \pm 24)\end{array}$ & $\begin{array}{c}264 \\
( \pm 128)\end{array}$ & 0 & 0 \\
\hline $\begin{array}{l}\text { Zhang } \\
\text { et al. } .^{[3]}\end{array}$ & 0 & 0 & 1 & 0 & 1 & 0 & 0 & NA & NA & NA & NA \\
\hline \multirow[t]{2}{*}{$\begin{array}{l}\text { Inoue } \\
\text { et al. }{ }^{[16] \#}\end{array}$} & 27 & $\begin{array}{c}7^{\text {th }} \text { and } \\
10^{\text {th }}\end{array}$ & 1 & 0 & 1 & 0 & 0 & $\begin{array}{c}216 \\
( \pm 39)\end{array}$ & $\begin{array}{c}157 \\
( \pm 120)\end{array}$ & 1 & 1 \\
\hline & 0 & 0 & 1 & 0 & 1 & 0 & 0 & $\begin{array}{c}241 \\
( \pm 77.5)\end{array}$ & $\begin{array}{c}100 \\
( \pm 62.5)\end{array}$ & 1 & 6 \\
\hline $\begin{array}{l}\text { Hirokawa } \\
\text { et al. }{ }^{[17] \&}\end{array}$ & \multicolumn{2}{|c|}{1 or $7^{\text {th }}$ and } & 1 & 0 & 1 & 1 & 0 & NA & NA & NA & NA \\
\hline & 0 & 0 & 1 & 0 & 1 & 1 & 0 & NA & NA & NA & NA \\
\hline $\begin{array}{l}\text { Chen } \\
\text { et al. }{ }^{[18]}\end{array}$ & 1 & $11^{\text {th }}$ & 0 & 1 & 1 & 0 & 1 & NA & NA & 0 & 0 \\
\hline $\begin{array}{l}\text { D'Hondt } \\
\text { et al. }{ }^{[19]}\end{array}$ & 0 & 0 & 0 & 0 & 1 & 1 & 1 & NA & NA & NA & 0 \\
\hline $\begin{array}{l}\text { Giuliani } \\
\text { et al. }{ }^{[20]}\end{array}$ & 0 & 0 & 0 & 0 & 1 & 0 & 0 & 240 & 220 & 0 & 0 \\
\hline $\begin{array}{l}\text { Ichida } \\
\text { et al. } .^{[2]]}\end{array}$ & $\begin{array}{c}1 \text { or } \\
2\end{array}$ & $\begin{array}{c}8^{\text {th }} \text { or } \\
9^{\text {th }}\end{array}$ & 1 & 0 & 1 & 0 & 1 & NA & NA & NA & 0 \\
\hline $\begin{array}{l}\text { Murata } \\
\text { et al. }{ }^{[22]}\end{array}$ & NA & NA & NA & NA & NA & NA & NA & NA & NA & NA & NA \\
\hline
\end{tabular}




\begin{tabular}{|c|c|c|c|c|c|c|c|c|c|c|c|}
\hline Authors & $\begin{array}{l}\text { ICT } \\
\text { No. }\end{array}$ & $\begin{array}{c}\text { ICT } \\
\text { place }\end{array}$ & $\begin{array}{c}\text { Pringle } \\
\text { maneuver }\end{array}$ & $\begin{array}{c}\text { Glissonean } \\
\text { approach }\end{array}$ & $\begin{array}{c}\text { Intraop. } \\
\text { USG }\end{array}$ & & $\begin{array}{l}\text { Fibrin } \\
\text { glue }\end{array}$ & $\begin{array}{c}\text { Operation } \\
\text { time }\end{array}$ & $\begin{array}{l}\text { Blood } \\
\text { loss } \\
(\mathrm{ml} / \mathrm{g})\end{array}$ & $\begin{array}{c}\text { Blood } \\
\text { transfusion } \\
\text { (min) }\end{array}$ & Conversion \\
\hline $\begin{array}{l}\text { Lainas } \\
\text { et al. }{ }^{[23]}\end{array}$ & 2 & NA & 0 & 0 & 1 & 0 & NA & 167 & 150 & 0 & 0 \\
\hline Li et al. ${ }^{[24]}$ & 0 & 0 & 1 & 0 & 0 & 0 & 0 & NA & NA & NA & 0 \\
\hline $\begin{array}{l}\text { Mashchenko } \\
\text { et al. }{ }^{[25]}\end{array}$ & 0 & 0 & 1 & 0 & 1 & 1 & 0 & $\begin{array}{c}272.5 \\
( \pm 44.5)\end{array}$ & $\begin{array}{c}291 \\
( \pm 57.5)\end{array}$ & 1 & 0 \\
\hline Kim et al. ${ }^{[26]}$ & NA & NA & 0 & 1 & 1 & 1 & 0 & 330 & 300 & 0 & 0 \\
\hline Lee et al. ${ }^{[27]}$ & 0 & 0 & 1 & 0 & 1 & 1 & 0 & $\begin{array}{c}151 \\
( \pm 63)\end{array}$ & $\begin{array}{c}294 \\
( \pm 281)\end{array}$ & 0 & 0 \\
\hline Our case 1 & 2 & $\begin{array}{c}9^{\text {th }} \text { and } \\
10^{\text {th }}\end{array}$ & 1 & 0 & 0 & 1 & 1 & 480 & 300 & 0 & 0 \\
\hline Our case 2 & 1 & $10^{\text {th }}$ & 1 & 0 & 0 & 1 & 1 & 600 & 3000 & 1 & 0 \\
\hline
\end{tabular}

fect the duration of operation, blood loss, and conversion to open surgery rates. We detected that CUSA usage only lowered the complication rates. Finally, Pringle maneuver had no effect on duration of surgery, blood loss, conversion to open surgery, and complications rates.

Surgeons had thought that the use of ICT may be successful to facilitate manipulation in a narrow space. ${ }^{[16,17]}$ The most preferred intercostal spaces were 7th and 10th and, the most common complications related to ICT placement were bleeding and pneumothorax. In our study, none of the patients had pneumothorax due to ICT. The usage of balloon trocars and closure of port holes had also been recommended to prevent pneumothorax. ${ }^{[17]}$ In our study, placement of ICT reduced the rate of conversion to open surgery and complications, although this was significant but recommended.

Bleeding in liver resections is directly proportional to post-operative morbidity and mortality. ${ }^{[29]}$ It is also known that bleeding is the most important factor affecting conversion to open surgery in laparoscopic liver resections. ${ }^{\text {[30] }}$ Pringle maneuver is the most common and oldest method preferred for bleeding control in liver resections. Pringle maneuver reduces bleeding by limiting blood flow to the liver by total clamping of the hepatoduodenal ligament. For isolated laparoscopic segment 7 resections, in a study comparing continuous semi-Pringle and intermittent Pringle maneuvers, semi-Pringle maneuver was shown to reduce operation time and bleeding. ${ }^{[3]}$ In this systematic review, Pringle maneuver was the most preferred method for bleeding control. However, Pringle maneuver had no significant effect on operation time and amount of bleeding. Glissonean approach, another inflow reduction method, is also preferred in laparoscopic liver resections. In Glissonean approach, Glisson pedicles are selectively isolated of at the entry site of liver and the portal triad of the relevant liver section is blocked to reduce blood flow. ${ }^{[31]}$ The disadvantage of this method is the possibility of iatrogenic injuries while looking for the intrahepatic isolations of segment 7 vascularity's. ${ }^{[32]}$ In this study, Glissonean technique prolonged the duration of surgery significantly. There was not any other significant relation between Glissonean approach, and the other surgical outcomes evaluated.

Parenchymal transection of liver is the bloodiest part of liver resections. Although many bleeding reduction methods are tried, the crush-clamp technique is the most effective method to reduce the amount of bleeding and additionally the duration of surgery. ${ }^{[33]}$ However, crushclamp method could not be used in laparoscopic liver resections effectively, and CUSA is an alternative device. CUSA breaks down and aspirates the parenchyma with ultrasonic waves to reveal vascular and bile structures, with

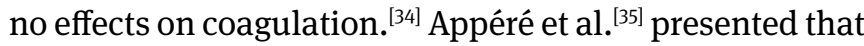
CUSA prolonged the duration of surgery and had no effect on the amount of bleeding, in their study comparing CUSA 
Table 3. Details of post-operative outcomes.

\begin{tabular}{|c|c|c|c|c|c|c|c|}
\hline Authors & $\begin{array}{l}\text { Bile } \\
\text { leak }\end{array}$ & Pneumothorax & $\begin{array}{l}\text { Dindo- } \\
\text { Clavien I }\end{array}$ & $\begin{array}{l}\text { Dindo- } \\
\text { Clavien II }\end{array}$ & $\begin{array}{c}\text { Dindo- } \\
\text { Clavien III }\end{array}$ & $\begin{array}{l}\text { Post-operative } \\
\text { stay (day) }\end{array}$ & Pathology \\
\hline Hilal et al. ${ }^{[4]}$ & NA & 0 & NA & NA & NA & NA & $\begin{array}{l}\text { Hepatic } \\
\text { splenosis }\end{array}$ \\
\hline Cho et al. ${ }^{[5]}$ & 0 & 0 & NA & NA & NA & NA & HCC/benign \\
\hline Cheng et al. ${ }^{[6]}$ & 0 & 0 & 0 & 0 & 0 & 6 & $\mathrm{HCC}$ \\
\hline Kazaryan et al. ${ }^{[1]}$ & NA & 0 & NA & NA & NA & NA & NA \\
\hline Ishizawa et al. ${ }^{[7]}$ & 0 & 0 & 0 & 0 & 0 & NA & NA \\
\hline Ikeda et al. ${ }^{[8]}$ & 0 & 0 & NA & NA & NA & NA & NA \\
\hline Long et al. ${ }^{[9]}$ & NA & NA & NA & NA & NA & NA & $\mathrm{HCC}$ \\
\hline Coles et al. ${ }^{[10]}$ & 0 & 0 & 2 & 0 & 0 & $4.6( \pm 2.5)$ & NA \\
\hline Lee et al. ${ }^{[11]}$ & 0 & 0 & 0 & 0 & 0 & NA & CRLM \\
\hline Okuda et al. ${ }^{[12]}$ & 0 & 0 & 0 & 0 & 0 & $6( \pm 0.5)$ & MET \\
\hline D'Hondt et al. ${ }^{[13]}$ & NA & 0 & NA & NA & NA & NA & NA \\
\hline \multirow[t]{2}{*}{ Ogiso et al. ${ }^{\left[{ }^{2{ }^{*}}\right.}$} & NA & 0 & NA & NA & NA & NA & NA \\
\hline & NA & 0 & NA & NA & NA & NA & NA \\
\hline Lim et al..$^{[14]}$ & NA & NA & NA & NA & NA & NA & NA \\
\hline Okuda et al. ${ }^{[15]}$ & 0 & 0 & 0 & 0 & 0 & $9( \pm 1.5)$ & $\begin{array}{c}2 \mathrm{CRLM} / \\
1 \mathrm{HCC}\end{array}$ \\
\hline Zhang et al..$^{[3]}$ & NA & 0 & NA & NA & NA & NA & NA \\
\hline \multirow[t]{2}{*}{ Inoue et al. ${ }^{[16] \#}$} & NA & 0 & 0 & 1 & 0 & $11( \pm 2.5)$ & $\begin{array}{l}4 \mathrm{HCC} / \\
11 \mathrm{MET}\end{array}$ \\
\hline & NA & 0 & 1 & 0 & 0 & $9.2( \pm 3.25)$ & $\begin{array}{l}7 \mathrm{HCC} / \\
7 \mathrm{MET}\end{array}$ \\
\hline Hirokawa & 0 & 0 & NA & NA & NA & NA & NA \\
\hline et al. ${ }^{[17] \&}$ & NA & 0 & NA & NA & NA & NA & NA \\
\hline Chen et al. ${ }^{[18]}$ & 0 & 0 & 0 & 0 & 0 & NA & $\mathrm{HCC}$ \\
\hline D'Hondt et al. ${ }^{[19]}$ & NA & 0 & NA & NA & NA & NA & NA \\
\hline Giuliani et al. ${ }^{[20]}$ & 0 & 0 & 0 & 0 & 0 & 5 & CRLM \\
\hline Ichida et al. $^{[21]}$ & 0 & 0 & 0 & 0 & 0 & NA & NA \\
\hline Murata et al. ${ }^{[22]}$ & NA & NA & NA & NA & NA & NA & Parasite \\
\hline Lainas et al. ${ }^{[23]}$ & 0 & 0 & 0 & 0 & 0 & 4 & $\mathrm{HCC}$ \\
\hline Li et al. ${ }^{[24]}$ & NA & 0 & NA & NA & NA & NA & NA \\
\hline $\begin{array}{l}\text { Mashchenko } \\
\text { et al. }{ }^{[25]}\end{array}$ & 0 & 0 & 0 & 2 & 2 & $9.5( \pm 4.5)$ & $\begin{array}{c}4 \text { HCC, CRLM, } \\
\text { ADE, HEM }\end{array}$ \\
\hline Kim et al. ${ }^{[26]}$ & 0 & 0 & 0 & 0 & 0 & 5 & HCC \\
\hline Lee et al. ${ }^{[27]}$ & NA & 0 & 0 & 0 & 2 & $6.1( \pm 1.5)$ & $\begin{array}{c}9 \mathrm{HCC}, 7 \mathrm{MET}, \\
1 \mathrm{FNH}\end{array}$ \\
\hline Our case 1 & 0 & 0 & 0 & 0 & 0 & 5 & $\begin{array}{l}\text { Fasciola } \\
\text { hepatica }\end{array}$ \\
\hline Our case 2 & 0 & 0 & 1 & 0 & 0 & 5 & $\mathrm{HCC}$ \\
\hline
\end{tabular}

HCC: Hepatocellular carcinoma, CRLM: Colorectal liver metastasis, MET: Metastatic tumor, ADE: Adenoma, HEM: Hemangioma, FNH: Focal nodular hyperplasia, NA: Not available data.

with ultrasonic scalpel in laparoscopic right hepatectomy. This systematic review showed, only the complications rates were reduced significantly by the use of CUSA. In our opinion, this controversial result may be explained by the design of the study; patients with blood loss undergoing conversion due to hemorrhage were excluded and only patients with blood loss who had a completed laparoscopy were enrolled. 
Table 4. Results of all available data

\begin{tabular}{|c|c|c|c|}
\hline Parameters & Outcomes (\%) & Parameters & Outcomes (\%) \\
\hline Age $(n=77)$ & $60.3 \pm 11.9$ & $8^{\text {th }}$ or $9^{\text {th }}$ & 4 \\
\hline Gender $(n=78)$ & $61.5 \%$ male & Pringle maneuver $(n=220)$ & $153(69.5)$ \\
\hline Tumor size $(n=48)$ & $2.8 \pm 1.4 \mathrm{~cm}$ & Glissonean approach $(n=238)$ & $32(13.4)$ \\
\hline Patient position $(\mathrm{n}=238)$ & & Intraoperative USG ( $n=225)$ & $183(76.8)$ \\
\hline Lateral (complete or semi) decubi & us $180(75.6)$ & CUSA $(n=232)$ & $78(33.6)$ \\
\hline Semi-prone & $30(15.9)$ & Fibrin sealant $(n=223)$ & $49(21.9)$ \\
\hline Supine & $20(8.4)$ & Operating time $(n=75)$ & $302 \pm 629 \mathrm{~min}$ \\
\hline Intercostal trocar $(n=231)$ & & Intraoperative blood loss $(n=81)$ & $249 \pm 460 \mathrm{ml}$ \\
\hline No & $141(61)$ & Blood transfusion $(n=81)$ & $37(45.6)$ \\
\hline Yes & $90(38.9)$ & Conversion $(n=178)$ & $8(4.5)$ \\
\hline One trocar & $31(34.4)$ & Post-operative complications $(\mathrm{n}=92)$ & $11(12)$ \\
\hline One or two trocars & $41(45.5)$ & Dindo-Clavien 1 & 4 \\
\hline Two trocars & $18(20)$ & Dindo-Clavien 2 & 3 \\
\hline Intercostal trocar locations $(\mathrm{n}=90)$ & & Dindo-Clavien 3 & 4 \\
\hline $6^{\text {th }}$ & 3 & Postoperative bile leak/fistula $(n=79)$ & 0 \\
\hline $7^{\text {th }}$ & 35 & Pneumothorax $(n=226)$ & 0 \\
\hline $8^{\text {th }}$ & 3 & Length of hospital stay $(n=75)$ & $7.9 \pm 3.3$ days \\
\hline $9^{\text {th }}$ & 10 & Pathologies $(n=86)$ & \\
\hline $10^{\text {th }}$ & 17 & Benign & $7(8.1)$ \\
\hline $11^{\text {th }}$ & 4 & $\mathrm{HCC}$ & $41(47.6)$ \\
\hline $7^{\text {th }}$ or $10^{\text {th }}$ & 14 & Metastasis & $38(44.1)$ \\
\hline
\end{tabular}

Table 5. Statistical analysis of technical procedures on surgical outcomes.

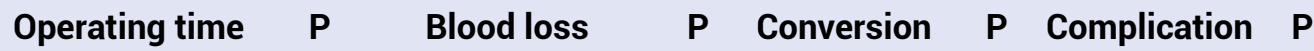 $(\mathrm{min}) \quad(\mathrm{ml})$}

\begin{tabular}{|c|c|c|c|c|c|c|c|c|}
\hline \multicolumn{9}{|l|}{ Patient position } \\
\hline Lateral decubitus & $(n=66) 226 \pm 90$ & 0.10 & $(n=66) 250 \pm 391$ & 0.76 & $(n=118) 8$ & 0.13 & $(n=83) 7$ & 0.01 \\
\hline Supine & $(n=8) 280 \pm 46$ & & $(n=8) 292 \pm 53$ & & $(n=20) 0$ & & $(n=8) 4$ & \\
\hline Semi-prone & NA & & NA & & $(n=38) 0$ & & NA & \\
\hline \multicolumn{9}{|l|}{$\begin{array}{l}\text { Intercostal trocar } \\
\text { placement }\end{array}$} \\
\hline Yes & $(n=27) 259 \pm 98$ & 0.09 & $(n=27) 261 \pm 559$ & 1.00 & $(n=76) 1$ & 0.07 & $(n=44) 2$ & 0.05 \\
\hline No & $(n=47) 220 \pm 91$ & & $(n=47) 261 \pm 280$ & & $(n=93) 7$ & & $(n=47) 9$ & \\
\hline \multicolumn{9}{|l|}{ Glissonean approach } \\
\hline Yes & $(n=4) 335 \pm 20$ & 0.02 & $(n=4) 273 \pm 106$ & 0.92 & $(n=32) 0$ & 0.35 & $(n=8) 0$ & 0.59 \\
\hline No & $(n=70) 226 \pm 89$ & & $(n=70) 253 \pm 406$ & & $(n=151) 8$ & & $(n=83) 11$ & \\
\hline \multicolumn{9}{|l|}{ CUSA } \\
\hline Yes & $(n=43) 236 \pm 107$ & NA & $(n=43) 341 \pm 497$ & NA & $(n=55) 1$ & 0.44 & $(n=46) 9$ & $<0.05$ \\
\hline No* & $(n=31) 266 \pm 60 *$ & & $(n=31) 133 \pm 97 *$ & & $(n=155) 7$ & & $(n=45) 2$ & \\
\hline \multicolumn{9}{|l|}{ Pringle maneuver } \\
\hline Yes & $(n=72) 232 \pm 91$ & 0.79 & $(n=71) 255 \pm 404$ & 0.80 & $(n=111) 7$ & 0.44 & $(n=84) 11$ & 0.59 \\
\hline No & $(n=3) 246 \pm 82$ & & $(n=3) 223 \pm 75$ & & $(n=47) 1$ & & $(n=7) 0$ & \\
\hline
\end{tabular}


In this review, the pathological examinations showed that the majority of liver resections were made for HCC and colorectal liver metastasis. We reported a case of Fasciola hepatica, a parasitic lesion, which had mimicked colorectal metastasis and a case of HCC, which developed on HCV-induced cirrhotic liver. It should be kept in mind that parasitic diseases may also be confused with colorectal cancer metastasis. Our case was the second parasitic lesion which was misdiagnosed as a tumor on liver segment 7 .

One of the limitations in this study was that most of the included studies' data were not solely for segment 7 liver lesions and the data of the patients who underwent laparoscopic segment 7 resection could not be reached clearly. Moreover, the second limitation was, not excluding liver resections combined with other organ resections.

\section{Conclusion}

This systematical review showed that lateral decubitus is the most chosen position that decreases the complication rates like using CUSA for parenchymal transection. In addition, the use of the ICTs for segment 7 liver resections decreases conversion to open surgery rates and may increase surgeon's manipulation capacity. We believe that laparoscopic resection of liver segment 7 may safely be performed in experienced centers using these technical features.

\section{Disclosures}

Peer-review: Externally peer-reviewed.

Conflict of Interest: None declared.

Authorship Contributions: Concept - K.S.; Design K.S., C.K.; Supervision - C.K.; Materials - K.S., C.K.; Analysis and/or interpretation - C.K., Y.M.B.; Literature search - K.S., C.K., O.G., F.S.; Writing - K.S., C.K.; Critical review - C.K., K.S.

\section{References}

1. Kazaryan AM, Røsok BI, Marangos IP, Rosseland AR, Edwin B. Comparative evaluation of laparoscopic liver resection for posterosuperior and anterolateral segments. Surg Endosc 2011;25:3881-9. [CrossRef]

2. Ogiso S, Conrad C, Araki K, Nomi T, Anil Z, Gayet B. Laparoscopic transabdominal with transdiaphragmatic access improves resection of difficult posterosuperior liver lesions. Ann Surg 2015;262:358-65. [CrossRef]

3. Zhang Y, Lu X, Xu J, Yang H, Deng X, Chen K, et al. Intermittent Pringle versus continuous half-pringle maneuver for laparo- scopic liver resections of tumors in segment 7 . Indian J Surg 2018;80:146-53. [CrossRef]

4. Hilal MA, Harb A, Zeidan B, Steadman B, Primrose J, Pearce $\mathrm{N}$. Hepatic splenosis mimicking HCC in a patient with hepatitis $\mathrm{C}$ liver cirrhosis and mildly raised alpha feto protein; the important role of explorative laparoscopy. World J Surg Oncol 2009;7:1. [CrossRef]

5. Cho JY, Han HS, Yoon YS, Shin SH. Outcomes of laparoscopic liver resection for lesions located in the right side of the liver. Arch Surg 2009;144:25-9. [CrossRef]

6. Cheng K, Yeung Y, Hui J, Ho K, Yip AW. Laparoscopic resection of hepatocellular carcinoma at segment 7: The posterior approach to anatomic resection. Surg Endosc 2011;25:3437.

7. Ishizawa T, Gumbs AA, Kokudo N, Gayet B. Laparoscopic segmentectomy of the liver: From segment I to VIII. Ann Surg 2012;256:959-64. [CrossRef]

8. Ikeda T, Toshima T, Harimoto N, Yamashita $\mathrm{Y}$, Ikegami $\mathrm{T}$, Yoshizumi T, et al. Laparoscopic liver resection in the semiprone position for tumors in the anterosuperior and posterior segments, using a novel dual-handling technique and bipolar irrigation system. Surg Endosc 2014;28:248492. [CrossRef]

9. Long TC, Bac NH, Thuan ND, Viet DQ. Laparoscopic liver resection: 5-year experience at a single center. Surg Endosc 2014;28:796-802. [CrossRef]

10. Coles S, Besselink M, Serin K, Alsaati H, Di Gioia P, Samim $M$, et al. Total laparoscopic management of lesions involving liver segment 7. Surg Endosc 2015;29:3190-5. [CrossRef]

11. Lee W, Han HS, Yoon YS, Cho JY, Choi Y, Shin HK. Role of intercostal trocars on laparoscopic liver resection for tumors in segments 7 and 8 . J Hepatobiliary Pancreat Sci 2014;21:E65-8. [CrossRef]

12. Okuda Y, Honda G, Kurata M, Kobayashi S, Sakamoto K, Takahashi K. A safe and valid procedure for pure laparoscopic partial hepatectomy of the most posterosuperior area: The top of segment 7. J Am Coll Surg 2015;220:e17-21. [CrossRef]

13. D'Hondt M, Yoshihara E, Vansteenkiste F, Steelant PJ, Van Ooteghem B, Pottel $\mathrm{H}$, et al. Laparoscopic parenchymal preserving hepatic resections in semiprone position for tumors located in the posterosuperior segments. Langenbecks Arch Surg 2016;401:255-62. [CrossRef]

14. Lim C, Ishizawa T, Miyata A, Mise $Y$, Sakamoto $Y$, Hasegawa $\mathrm{K}$, et al. Surgical indications and procedures for resection of hepatic malignancies confined to segment VII. Ann Surg 2016;263:529-37. [CrossRef]

15. Okuda $Y$, Honda G, Kobayashi S, Sakamoto K, Homma $Y$, Honjo $\mathrm{M}$, et al. Intrahepatic Glissonean pedicle approach to segment 7 from the dorsal side during laparoscopic anatomic hepatectomy of the cranial part of the right liver. $J$ Am Coll Surg 2018;226:e1-6. [CrossRef]

16. Inoue Y, Suzuki Y, Fujii K, Kawaguchi N, Ishii M, Masubuchi S, et al. Laparoscopic liver resection using the lateral approach from intercostal ports in segments VI, VII, and VIII. J Gastrointest Surg 2017;21:2135-43. [CrossRef]

17. Hirokawa F, Hayashi $M$, Asakuma $M$, Shimizu $T$, Inoue $Y$, 
Uchiyama K. Intercostal Trocars enable easier laparoscopic resection of liver tumors in segments 7 and 8 . World J Surg 2017;41:1340-6. [CrossRef]

18. Chen JC, Zhang RX, Chen MS, Xu L, Chen JB, Yang KL, et al. Left jackknife position: A novel position for laparoscopic hepatectomy. Chin J Cancer 2017;36:31. [CrossRef]

19. D'Hondt M, Tamby E, Boscart I, Turcotte S, Parmentier I, Pottel $\mathrm{H}$, et al. Laparoscopic versus open parenchymal preserving liver resections in the posterosuperior segments: A casematched study. Surg Endosc 2018;32:1478-85. [CrossRef]

20. Giuliani A, Bianco P, Guerra G, Rocca A, Calise F. Totally laparoscopic liver resection for colorectal metastasis located in segment 7 in a patient with situs inversus totalis. J Surg Case Rep 2017;2017:rjw243. [CrossRef]

21. Ichida $H$, Ishizawa $T$, Tanaka M, Terasawa M, Watanabe G, Takeda $Y$, et al. Use of intercostal trocars for laparoscopic resection of subphrenic hepatic tumors. Surg Endosc 2017;31:1280-6. [CrossRef]

22. Murata $Y$, Ando $K$, Usui $M$, Sugiyama $H$, Hayashi $A$, Tanemura $A$, et al. A case of hepatic anisakiasis caused by Pseudoterranova decipiens mimicking metastatic liver cancer. BMC Infect Dis 2018;18:619. [CrossRef]

23. Lainas P, Ferretti S, Dagher I. Laparoscopic liver resection for segment VII hepatocellular carcinoma in a cirrhotic patient [with video]. J Visc Surg 2018;155:423. [CrossRef]

24. Li J, Ren H, Du G, Jin B. A systematic surgical procedure: The '7+ 3' approach to laparoscopic right partial hepatectomy [deep segment [S] VI, S VII or S VIII] in 52 patients with liver tumors. Oncol Lett 2018;15:7846-54. [CrossRef]

25. Mashchenko I, Trtchounian A, Buchholz C, de la Torre AN. A sling technique for laparoscopic resection of segment seven of the liver. JSLS 2018;22:e2018.00017. [CrossRef]

26. Kim S, Han HS, Sham JG, Yoon YS, Cho JY. Laparoscopic anatomical S7 segmentectomy by the intrahepatic glissonian approach. Surg Oncol 2019;28:158. [CrossRef]

27. Lee JW, Choi SH, Kim S, Kwon SW. Laparoscopic liver resec- tion for segment VII lesion using a combination of rubber band retraction method and flexible laparoscope. Surg Endosc 2019;34:954-60. [CrossRef]

28. Hozo SP, Djulbegovic B, Hozo I. Estimating the mean and variance from the median, range, and the size of a sample. BMC Med Res Methodol 2005;5:13. [CrossRef]

29. Maurer CA, Walensi M, Käser SA, Künzli BM, Lötscher R, Zuse A. Liver resections can be performed safely without pringle maneuver: A prospective study. World J Hepatol 2016;8:1038.

30. Troisi RI, Montalti R, Van Limmen JG, Cavaniglia D, Reyntjens $\mathrm{K}$, Rogiers $\mathrm{X}$, et al. Risk factors and management of conversions to an open approach in laparoscopic liver resection: analysis of 265 consecutive cases. HPB 2014;16:75-82.

31. Yamamoto $M$, Ariizumi Si. Glissonean pedicle approach in liver surgery. Ann Gastroenterol Surg 2018;2:124-8. [CrossRef]

32. Sugioka A, Kato Y, Tanahashi Y. Systematic extrahepatic glissonean pedicle isolation for anatomical liver resection based on Laennec's capsule: Proposal of a novel comprehensive surgical anatomy of the liver. J Hepatobiliary Pancreat Sci 2017;24:17-23. [CrossRef]

33. Liu F, Wei $Y$, Li H, Wang W, Wen T, Wu H, et al. LigaSure versus CUSA for parenchymal transection during laparoscopic hepatectomy in hepatocellular carcinoma patients with cirrhosis: A propensity score-matched analysis. Surg Endosc 2018;32:2454-65. [CrossRef]

34. Huang KW, Lee PH, Kusano T, Reccia I, Jayant K, Habib N. Impact of cavitron ultrasonic surgical aspirator [CUSA] and bipolar radiofrequency device [Habib-4X] based hepatectomy for hepatocellular carcinoma on tumour recurrence and disease-free survival. Oncotarget 2017;8:93644. [CrossRef]

35. Appéré $F$, Piardi $T$, Memeo $R$, Lardière-Deguelte $S$, Chetboun $M$, Sommacale $D$, et al. Comparative study with propensity score matching analysis of two different methods of transection during hemi-right hepatectomy: Ultracision harmonic scalpel versus cavitron ultrasonic surgical aspirator. Surg Innov 2017;24:499-508. [CrossRef] 